\title{
ARTIST (Asian regional tobacco industry scientist team): Philip Morris' attempt to exert a scientific and regulatory agenda on Asia
}

\author{
E K Tong, S A Glantz
}

Tobacco Control 2004;13(Suppl II):ii1 18-ii124. doi: 10.1136/tc.2004.009001

See end of article for authors' affiliations

\section{Correspondence to:} Stanton A Glantz, PhD, Box 1390, University of California, San Francisco, San Francisco, CA 94143-1390, USA glantz@medicine.ucsf.edu

\begin{abstract}
Objective: To describe how the transnational tobacco industry has collaborated with local Asian tobacco monopolies and companies to promote a scientific and regulatory agenda.

Methods: Analysis of previously secret tobacco industry documents.

Results: Transnational tobacco companies began aggressively entering the Asia market in the 1980s, and the current tobacco industry in Asia is a mix of transnational and local monopolies or private companies. Tobacco industry documents demonstrate that, in 1996, Philip Morris led an organisation of scientific representatives from different tobacco companies called the Asian Regional Tobacco Industry Science Team (ARTIST), whose membership grew to include monopolies from Korea, China, Thailand, and Taiwan and a company from Indonesia. ARTIST was initially a vehicle for PM's strategies against anticipated calls for global smoke-free areas from a World Health Organization secondhand smoke study. ARTIST evolved through 2001 into a forum to present scientific and regulatory issues faced primarily by Philip Morris and other transnational tobacco companies. Philip Morris' goal for the organisation became to reach the external scientific and public health community and regulators in Asia.

Conclusion: The Asian tobacco industry has changed from an environment of invasion by transnational tobacco companies to an environment of participation with Philip Morris' initiated activities. With this participation, tobacco control efforts in Asia face new challenges as Philip Morris promotes and integrates its scientific and regulatory agenda into the local Asian tobacco industry. As the local Asian tobacco monopolies and companies can have direct links with their governments, future implementation of effective tobacco control may be at odds with national priorities.
\end{abstract}

$\mathrm{T}$ he transnational tobacco industry exporting cigarettes into Asia has been compared to an "opium war" of Western invasion and Asian resistance. ${ }^{1}$ Tobacco industry documents have demonstrated marketing strategies to Asians in the USA ${ }^{2}$ and overseas, ${ }^{3}$ and tobacco industry tactics need to be monitored to counter industry targeting. ${ }^{4}$ With the world's highest percentages of smokers over 15 years old living in Asia and the Pacific, ${ }^{6}$ effective tobacco control measures are urgently needed.

In the mid1980s, trade barriers from state owned Asian tobacco monopolies were dismantled by the US Trade Representative office in Taiwan, Thailand, South Korea, and Japan, and smoking consumption by 1991 in these countries was $10 \%$ higher than if the markets had remained closed to US cigarettes. ${ }^{7}$ Today, the tobacco industry competitors within Asia remain a mix of transnational companies, state owned tobacco monopolies, and private Asian tobacco companies. For example, India's cigarette market (the tobacco market mostly consists of bidis or chewing tobacco) is dominated by Indian Tobacco Company of which British American Tobacco owns a third, Indonesia's cigarette market is dominated by three local tobacco companies (the tobacco market mostly consists of kreteks), and China's cigarette market is dominated by a state owned monopoly $(99.4 \%$ market share in 1997). ${ }^{8}$ Of note, China has the world's largest smoking market that the transnational tobacco companies have highly anticipated entering, ${ }^{3}$ and trade tariffs are being gradually reduced while China's monopoly is restructuring after China's 2002 entry into the World Trade Organization. ${ }^{9}$

The effectiveness of tobacco control in Asia depends on both the extent of trade liberalisation and the priority placed by national governments on tobacco control, as seen by the current state of Asian markets that opened to the transnational companies in the 1980s. Thailand has been a model of strong tobacco control, with its own tobacco monopoly accepting regulations that the transnational industry fought. ${ }^{10}$ In contrast, Japan Tobacco privatised its monopoly in 1985 (although the Ministry of Finance still owns two thirds of the company) and became the world's third largest multinational tobacco company after buying RJ Reynolds' international division in 1999; tobacco control in Japan has been limited because of conflicting government interests ${ }^{11}{ }^{12}$ and Japan Tobacco has learned strategies to minimise public concern regarding health risks from Philip Morris (PM). ${ }^{13}$ Similarly, Korea's relationship between its government and monopoly had not led to effective tobacco control policies, with a high male smoking prevalence of $66 \%,{ }^{14}$ although the monopoly has privatised since 2001 and a significant tobacco tax has been implemented. In 2004, Taiwan started privatising its monopoly after its 2002 entry into the World Trade Organization, ${ }^{15}$ but managed to implement a significantly increased tobacco tax. ${ }^{16}$ With such heterogeneity, understanding the challenges for tobacco control in the Asian region is important.

\footnotetext{
Abbreviations: ARTIST, Asian Regional Tobacco Industry Science Team; ATIEST, Asian Tobacco Industry ETS Science Team; CECCM, Confederation of European Community Cigarette Makers; CNTC, China National Tobacco Corporation; CORESTA, Cooperation Centre for Scientific Research Relative to Tobacco; ETS, environmental tobacco smoke; IARC, International Agency for Research on Cancer; INFOTAB, International Tobacco Information Center; KGTRI, Korean Ginseng and Tobacco Research Institute; PM, Philip Morris; WHO, World Health Organization
} 
The transnational industry may no longer be an "invader" for indigenous Asian tobacco companies, but may now be seen by these companies as an invaluable collaborator. In 1996, PM wanted to organise its Asian regional interests and began constructing an industry organisation, the Asian Regional Tobacco Industry Scientists Team (ARTIST) to organise the region's tobacco companies. In contrast to earlier international efforts by Philip Morris and other transnational tobacco companies that were directed at the public and public policy makers, ${ }^{17-19}$ such as the Asian secondhand smoke scientific consultant programme, ${ }^{2021}$ the new organisation sought to develop communication and coordination among the tobacco companies within Asia. PM's original motivation was concern that smoke-free policies would spread throughout the region after the publication of a World Health Organization study ${ }^{22}$ on secondhand smoke and lung cancer. As previously described, PM was leading the transnational tobacco industry in a multimillion dollar campaign to counteract the study's impact before it was published, by developing scientific studies and communication programmes. ${ }^{23}$ Over six years, ARTIST grew to incorporate representatives from the major Asian tobacco monopolies, and became a forum to present scientific and regulatory issues faced by the transnational companies.

\section{METHODS}

We retrieved documents from the Legacy Tobacco Documents Library from searches between September 2003 and March 2004. Keywords included "ARTIST" and names of key players and organisations. We determined that 38 documents were relevant in describing the formation of ARTIST and its agendas. Searches in www.tobaccodocuments.org and a preliminary collection of documents for the Guildford Archiving Project ${ }^{24}$ from the Guildford, England depository did not produce additional relevant documents.

\section{RESULTS}

\section{Recruiting ARTIST's membership}

PM held meetings to inform other tobacco companies about its plans to counteract the anticipated WHO International Agency for Research on Cancer's (IARC) secondhand smoke study. ${ }^{23}$ PM was worried that the IARC secondhand smoke study, finally published in 1998, would show that exposed non-smokers would have an increased risk for lung cancer and lead to increased smoke-free areas around the world..$^{23}$ In March 1996, Roger Walk, a research scientist from PM who led preparations for an industry response to the IARC study in Asia, held a meeting in Hong Kong to describe PM's concerns and efforts. An interested Korean tobacco industry scientist, Dr Dong Wook Lee, chief of the biochemistry laboratory of Korean Ginseng and Tobacco Research Institute (KGTRI), attended PM's initial meeting in Hong Kong. ${ }^{25} \mathrm{Dr}$ Yukio Ohkawa, senior vice president of Japan Tobacco's science and global environment planning, also attended the meeting, and together all three planned a May 1996 meeting in Seoul, Korea for interested scientists and executives from other Asian tobacco monopolies and companies. ${ }^{25}$

PM's Dr Walk took the lead in inviting other initial members and directing the agenda of the first meeting. ${ }^{26} \mathrm{Dr}$ Charles Green, principal scientist of research and development from RJ Reynolds, and Dr PP Singh, from British American Tobacco's India Tobacco Company, joined the first meeting of ARTIST on May 1996 in Seoul, Korea. ${ }^{27}$ Dr Walk would be the first Secretary leading ARTIST, followed by Dr Yukio Akiyama, director of Japan Tobacco's scientific information division, in $1999 .{ }^{28}$ Since 1993, besides sharing a joint Marlboro licensure agreement, PM and Japan Tobacco executives had started "to exchange information on

Table 1 Asian Regional Tobacco Industry Science Team (ARTIST) members and invited speakers ${ }^{27}$ 30-38

\begin{tabular}{|c|c|}
\hline \multirow{2}{*}{\multicolumn{2}{|c|}{ May 1996 (first meeting) }} \\
\hline & \\
\hline Yukio Akiyama, PhD & $\begin{array}{l}\text { Vice president scientific information division, } \\
\text { Japan Tobacco }\end{array}$ \\
\hline Charles Green, PhD & $\begin{array}{l}\text { Principal scientist/manager research and } \\
\text { development, RJ Reynolds }\end{array}$ \\
\hline Dr Dong Wook Lee & $\begin{array}{l}\text { Chief of biochemistry laboratory, Korean } \\
\text { Ginseng and Tobacco Research Institute }\end{array}$ \\
\hline Dr Yukio Ohkawa & $\begin{array}{l}\text { Associate group director science and global } \\
\text { environment planning, Japan Tobacco }\end{array}$ \\
\hline PP Singh, PhD & India Tobacco Company, Ltd \\
\hline Dr Roger Walk & $\begin{array}{l}\text { Research fellow, scientific affairs Asia/ } \\
\text { Japan/Australia } \\
\text { INBIFO, for Philip Morris }\end{array}$ \\
\hline \multicolumn{2}{|l|}{ Attendees through April 2001} \\
\hline \multicolumn{2}{|l|}{ Transnational companies } \\
\hline Richard Carchman & $\begin{array}{l}\text { Manager, scientific affairs, Philip Morris } \\
\text { USA }\end{array}$ \\
\hline Raymond Lau, PhD & Philip Morris Asia \\
\hline Hasan Sulaiman, PhD & $\begin{array}{l}\text { Director of public affairs, RJ Reynolds } \\
\text { Malaysia (later transferred to Philip Morris) }\end{array}$ \\
\hline K Takada, PhD & $\begin{array}{l}\text { Associate scientist, scientific affairs, Philip } \\
\text { Morris Japan } \\
\text { Kabushiki Kaisha }\end{array}$ \\
\hline Dr Anthony Tricker & Philip Morris Neuchatel \\
\hline Mingda Zhang, PhD & $\begin{array}{l}\text { Associate scientist, scientific affairs, Philip } \\
\text { Morris } \\
\text { Asia/Japan/Australia }\end{array}$ \\
\hline Dr W Rahn & Reemtsma \\
\hline S Sears, PhD & RJ Reynolds \\
\hline John Robinson & Master scientist, RJ Reynolds \\
\hline Dr D Rowland & $\begin{array}{l}\text { Public affairs specialist in scientific \& } \\
\text { technical issues, Rothmans International }\end{array}$ \\
\hline Dr Linda Rudge & $\begin{array}{l}\text { Scientific issues manager, Wills, British } \\
\text { American Tobacco Australia }\end{array}$ \\
\hline Clausen Ely & Covington and Burling law firm \\
\hline \multicolumn{2}{|r|}{ - } \\
\hline $\mathrm{X}$ Han & China Tobacco Society \\
\hline T Jia & China Tobacco Society \\
\hline S Li & $\begin{array}{l}\text { China State Tobacco Monopoly } \\
\text { Administration (STMA) }\end{array}$ \\
\hline Baizhan Liu & Hefei Economic Technology College (invited) \\
\hline Gangyi Liu & $\begin{array}{l}\text { Department of Science and Education of } \\
\text { CNTC (invited) }\end{array}$ \\
\hline DQu & China Tobacco Society \\
\hline Dr Jianping Xie & $\begin{array}{l}\text { Senior chemist, Zhengzhou Tobacco } \\
\text { Research Institute, China } \\
\text { National Tobacco Corporation }\end{array}$ \\
\hline X Zhao & China Tobacco Society \\
\hline Mingyue Zhou & $\begin{array}{l}\text { Zhengzhou Tobacco Research Institute of } \\
\text { CNTC (invited) }\end{array}$ \\
\hline Ms Tianwei Zhou & $\begin{array}{l}\text { Director development and promotion } \\
\text { department, science and } \\
\text { technology and education division, China } \\
\text { State Tobacco Monopoly Administration } \\
\text { (STMA) }\end{array}$ \\
\hline \multicolumn{2}{|r|}{ (f) } \\
\hline Dr DH Piehl & PTHM Sampoerna \\
\hline M Sholichin, PhD & PTHM Sampoerna \\
\hline \multicolumn{2}{|l|}{ Japan } \\
\hline T lkeda, PhD & $\begin{array}{l}\text { Director scientific information division, Japan } \\
\text { Tobacco }\end{array}$ \\
\hline Dr DC Rees & Japan Tobacco International (JTISA) \\
\hline $\begin{array}{l}\text { Dr N Sinclair } \\
\text { Thailand }\end{array}$ & Japan Tobacco International \\
\hline Ms Mookda Chantrapornchai & $\begin{array}{l}\text { Head of research and development, Thailand } \\
\text { Tobacco Monopoly }\end{array}$ \\
\hline \multicolumn{2}{|r|}{ 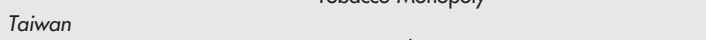 } \\
\hline S-C Chan & Taiwan Tobacco \& Wine Bureau \\
\hline Dr Wen-yen Chen & Taiwan Tobacco \& Wine Bureau \\
\hline \multicolumn{2}{|l|}{ Mini-symposia speakers } \\
\hline Professor Sung-Ok Baek & Yeungham University, Korea \\
\hline Professor Yu-Tang Gao & Shanghai Cancer Institute, China \\
\hline Professor T Kawamoto & $\begin{array}{l}\text { University of Occupational and } \\
\text { Environmental Health, Japan }\end{array}$ \\
\hline Dr Yasushi Kodama & $\begin{array}{l}\text { Professor Emeritus, University Occupational } \\
\text { and Environmental Health, Japan }\end{array}$ \\
\hline Professor H Matsuki & Tokai University, Japan \\
\hline Dr G Scherer & $\begin{array}{l}\text { ABF (Analytisch Biologisches Forschungs), } \\
\text { Germany }\end{array}$ \\
\hline Thomas Starr, PhD & $\begin{array}{l}\text { TBS Associates, USA; ENVIRON } \\
\text { International Corporation }\end{array}$ \\
\hline Robert Tardiff & Sapphire Group, Maryland USA \\
\hline Professor Wenjuan Xin & Institute of Biophysics, China \\
\hline
\end{tabular}

May 1996 (first meeting)

Dr Yukio Ohkawa

PP Singh, PhD

Attendees through April 200

Transnational companies

K Takada, PhD

Dr Anthony Tricker

Mingda Zhang, PhD

Dr W Rahn

$S$ Sears, PhD

John Robinson

Dr Linda Rudge

Clausen

$X$ Han

$T$ Jia

Gangyi Liu

D Qu

$X$ Zhao

Mingyue Zho

Ms Tianwei Zhou

M Sholichin, Ph

Japan

Ms Mookda Chantrapornchai

Taiwan

Dr Wen-yen Chen

Mini-symposia speakers

Professor T Kawamoto

Professor Wenjuan Xin 
substantive smoking and health issues" and to "begin a regular pattern of contact and exchange of scientific and 'legal' issues information". ${ }^{29}$

ARTIST gradually recruited Asian tobacco monopolies and private companies (table 1), and held meetings throughout Asia (table 2) that occasionally included a "mini-symposium" of invited speakers (table 1). ${ }^{27}{ }^{30-38}$

In November 1996, China's Dr Jianping Xie, a senior chemist at Zhengzhou Tobacco Research Institute of China National Tobacco Corporation (CNTC), attended the second meeting, ${ }^{30}$ and was sometimes later joined by other representatives from China's tobacco monopoly. In September 1997, Indonesia's PTHM Sampoerna, a private tobacco company, attended ARTIST's fourth meeting. ${ }^{32}$ By November 1997, Thailand Tobacco Monopoly's Mookda Chantrapornchai, head of research and development, had joined. ${ }^{39}$ The Taiwan Tobacco and Wine Board joined by September 1999.40 With the monopolies recruited into ARTIST by 1999, PM's Raymond Lau stated:

\section{ARTIST has grown from a small group of scientists representing multinational tobacco companies to an organization which incorporates the local monopolies, who are the dominant key players in the industry in Asia. More than ever, ARTIST now serves as an effective forum for the sharing of non-competitive scientific information and help raise the quality of scientific research in tobacco related topics in the region. ${ }^{40}$}

The inclusion of the scientific representatives from local Asian monopolies and companies enriched ARTIST's membership in reflecting the Asian tobacco industry. Although meeting sites included Malaysia, Singapore, and Hong Kong, more transnational industry representation from these highly penetrated markets beyond the regional representatives did not seem to be needed. ${ }^{41}$ It is not clear from the documents about the motivations of each Asian tobacco company's representative in joining ARTIST.

\section{Charting Philip Morris' goals into ARTIST's goals}

The primary interest for ARTIST is reflected in its original name, "Asian Tobacco Industry ETS [environmental tobacco smoke, the industry's term for secondhand smoke] Science Team" (ATIEST). ${ }^{42}$ The "Team objectives and goals", developed by PM's Walk for the first meeting, demonstrate that its purpose was preventing smoke-free areas in Asia:

- Objectives

- Exchange information on ETS (S\&H) [smoking and health] science

\begin{tabular}{|c|c|c|}
\hline $\begin{array}{l}\text { ARTIST } \\
\text { meeting }\end{array}$ & Date & Location \\
\hline 1 & May 1996 & Seoul, Korea \\
\hline 2 & November 1996 & Yokohama, Japan \\
\hline 3 & May 1997 & Hong Kong \\
\hline 4 & September 1997 & Kuala Lumpur, Malaysia \\
\hline 5 & April 1998 & Shanghai, China \\
\hline 6 & January 1999 & Bangkok, Thailand \\
\hline 7 & October 1999 & Kyoto, Japan \\
\hline 8 & April 2000 & Beijing, China \\
\hline 9 & November 2000 & Hong Kong \\
\hline 10 & May 2001 & Singapore \\
\hline
\end{tabular}

- Exchange information on company positions on ETS (S\&H) science

- Develop personal basis for cooperation

- Initiate and execute project activities

- Discuss the legal and regulatory issues involving scientists

- Evaluate scientific publications

- Develop scientific industry materials

- Goal

- To put scientific claims based on US or European data into a regional perspective

- To support the introduction of new technologies for improvement of indoor air quality

- To support an environment where smokers and nonsmokers can comfortably coexist

- To support good science [comments added] ${ }^{27}$

The objectives describe the purpose in discussing scientific and regulatory issues, and collaborating on projects within the Asian region. The four goals reflect previously described activities ${ }^{17} 23{ }^{43-47}$ by PM to prevent smoke-free areas from a scientific and regulatory basis. First, PM had been working against conclusions secondhand smoke caused disease throughout Asia: PM was funding personal monitoring studies of smoke exposure throughout Asia to counteract the IARC study, ${ }^{23}$ led an Asian consultant programme to influence public opinion on secondhand smoke, ${ }^{2021}$ and funded a study ${ }^{43}$ that was generated specifically to refute a landmark Japanese study on lung cancer in non-smokers. ${ }^{44}$ Second, the goal of introducing technologies for indoor air quality is consistent with PM's efforts to present ventilation as an alternative for smoke-free areas. ${ }^{45}$ Third, environments for smokers and non-smokers to coexist reflects PM's "Accommodation" programme for businesses to adopt ventilation technologies. ${ }^{46}{ }^{47}$ Fourth, the goal to support "good science" reflects PM's "sound science" public relations campaign to criticise epidemiologic secondhand smoke disease studies as weak. ${ }^{17}$ ARTIST would be the forum for PM to encourage other companies to adopt its goals.

PM's executives solidified their goals for the Asian region by having their lawyers construct a charter for ARTIST in 1998-9. The charter's purpose similarly describes discussion of scientific research, introducing ventilation technologies for accommodating smokers and non-smokers, and considering scientific developments in the context of Asia (table 3). ${ }^{48}$

The charter specifically states ARTIST would not make statements about health risks of tobacco products, nor fund or conduct research on health issues or new products. ${ }^{48}$ Meetings would be held twice a year, and membership is open to "all scientists or other technically competent individuals employed by tobacco companies" in Asia. ${ }^{48}$ One point debated within PM was whether to have member only meetings or public forums. With $\mathrm{PM}^{\prime}$ s assistant general counsel suggesting "not permitting member-only meetings may mean the end of the organization", ${ }^{49}$ Cathy Ellis, senior vice president of Philip Morris' worldwide scientific affairs, decided that member-only meetings would be appropriate if "typical of any scientist to scientist interaction and that these discussions not be considered proprietary in any way". ${ }^{50}$ As a result, ARTIST could have public forums open to any scientist interested in Asia, but there would still be private sessions in which "participation in non-public scientific discussions is open only to members". ${ }^{48}$ Retaining the exclusive industry component suggested that ARTIST was not meant by PM to fully include the general scientific community. The charter 
Table 3 ARTIST charter drafted by Philip Morris' law firm Covington \& Burling ${ }^{48}$

(1) To contribute to the quality of scientific research on topics related to tobacco

- Communication of scientific literature

- Discussion of scientific research with the aim of identifying areas for further research

- Informing members about current scientific developments in countries of the Asia-Pacific region

(2) To support the introduction of technologies for the accommodation of both smoking and non-smoking individuals in an environment where they can comfortably coexist

- Communication of scientific literature regarding indoor air quality (IAQ) and heating, ventilation and air conditioning (HVAC) systems

- Discussion of IAQ and HVAC research with the aim of identifying areas for further research

- Informing members about current scientific developments related to $I A Q$ and $H V A C$ technologies

(3) To discuss, review, and consider scientific developments in the context of research conducted in the Asia-Pacific region

ARTIST has not been constituted in order to, and under no circumstances shall it:

(1) make any statements (either public or non-public) regarding the health risks associated with, or any other consequences of, using any tobacco product

(2) fund or conduct (either directly or indirectly) any research relating to smoking and health

(3) fund or conduct (either directly or indirectly) any research relating to the marketing or development of new tobacco products

was presented to ARTIST members, who approved it without comment in early 1999. ${ }^{51}$

\section{ARTIST agenda: preparing Asia against the IARC study}

The topic that consistently appeared on ARTIST's agenda for the first four meetings between 1996 and $1997^{47}$ was updates on "Asia-specific IARC preparation", as countering the IARC secondhand smoke study was the initial reason ARTIST had been formed. A 1997 PM ARTIST presentation described PM's position that the IARC study "would still add only one more study to the pool of research on ETS, the balance of which fails to establish an association between ETS and lung cancer", and "suffers from several design limitations".52 Updates were provided about the study's data availability from conference proceedings and anticipated publication, ${ }^{32}$ and the progress of PM's ongoing global personal monitoring studies designed to counteract the study results. ${ }^{31}$ Personal monitoring studies were also planned for Japan and Korea, ${ }^{27}$ with funding from the "Joint JT-PM Asian Consultant Program". ${ }^{53}$

Communication projects of PM, adopted by Japan Tobacco and other transnational companies, were developed to prepare the Asian tobacco industry against the IARC study's publication. An Asian "IARC Response Plan", presented by Japan Tobacco's Akiyama in 1997,, ${ }^{31}$ was promoted to coordinate an Asian regional response when the IARC study was published. A flow chart shows that after the European industry analysed the study and created an official media statement, cleared by legal, scientific, and communications departments, the statement would be adapted to Asian regional needs before release to the media. ${ }^{54} \mathrm{PM}^{\prime} \mathrm{s}$ Walk ${ }^{55}$ and RJ Reynolds' Charles Green ${ }^{31}$ updated ARTIST members on "Good Epidemiology Practices", and PM's Walk wanted to raise awareness about it within the scientific community and regulators in Asia. ${ }^{55}$ As previously described, ${ }^{17}$ the "Good Epidemiology Practices" project was PM's failed attempt to have legitimate international epidemiologic organisations adopt guidelines criticising relative risks less than 2.0, such as in secondhand smoke studies. A Guangzhou 1997 conference was held between the transnational industry's
Center for Indoor Air Research and external consultants, and the Chinese Epidemiological Association. ${ }^{17}$

A 100 page Scientific resource book summarising Asia region specific secondhand smoke science was compiled and edited by PM scientists Roger Walk and Mingda Zhang. ${ }^{56}$ This book was finished in 1997 and distributed to ARTIST members, who had been asked to help with reviewing, correcting, and supplementing the information. The review covered lung cancer epidemiology and risk factors for Asia, personal monitoring exposure studies in Asia, and heart disease epidemiology in Asia. Not surprisingly, ${ }^{57}$ the book concludes: "It is clear from the Asian studies that evidence suggesting ETS might cause or might be statistically associated with lung cancer is very weak", and suggests "other factors [than smoking] are predominantly responsible for the marked variation in lung cancer rates in China" ${ }^{56}$ The appendix includes "Asia Quotations" from British American Tobacco about secondhand smoke studies to refute the "negativity of the media on ETS" which stemmed from a Western trend: "the campaign against smoking is in fashion, or has become politically correct, particularly in much of the West". ${ }^{56}$ After the IARC study was published in 1998 and did not lead to immediate global smoke-free areas, ${ }^{23}$ the ARTIST agendas began to cover a wider scope of PM's goals for ARTIST.

\section{ARTIST agenda: establishing scientific communication within the Asian tobacco industry}

The agendas for the ARTIST meetings expanded after the IARC secondhand smoke study was published. For the first four meetings, ${ }^{27}$ 30-32 "Asia-specific IARC preparation" was on the agenda, along with discussing related events like the Beijing World Conference on Smoking and Health or the UK government's secondhand smoke report (SCOTH). A variety of agenda presentation topics followed, with some ARTIST meetings described as "mini-symposia" and including nonindustry speakers from universities and private consulting groups (table 1). Some of the professors from the universities had received funds for consulting work done for the industry, noted below. The transnational tobacco industry, led by PM, had developed an "International ETS Consultant Program" to "keep the controversy alive" on secondhand smoke by recruiting consultants to develop and promote scientific viewpoints favourable to the industry. ${ }^{18} 19$

Various scientific issues were presented by various tobacco company representatives or invited speakers. On the molecular and biochemical level were metabolic polymorphisms and genetic susceptibility (PM), ${ }^{31}$ genetics and nicotine metabolism plus lung cancer susceptibility (PM)," "benchmark" level studies of smoke constituents by multiple US tobacco companies (PM), ${ }^{34}$ and biomarkers of smoking (PM; Reemtsma; Scherer, Germany's ABF; Kawamoto, Japan's University of Occupational and Environmental Health; Matsuki, Japan's Tokai University). ${ }^{35}$ On an epidemiologic level were risk factors for lung cancer (Gao, Shanghai Cancer Institute), ${ }^{36}$ and childhood diseases and secondhand smoke (PM). ${ }^{37}$ For smoker and non-smoker exposure experiments, topics included review of personal monitor exposure studies (PM), ${ }^{33}$ smoker compensation for nicotine levels (Japan Tobacco), ${ }^{38}$ risk measuring indoor secondhand smoke levels (Baek, Korea's Yeungham University),, ${ }^{36}$ and secondhand smoke levels for non-smokers in offices (Korea). ${ }^{34}$ For nonhuman discussions, topics included secondhand smoke neurotoxicity in rats (Korea), ${ }^{34}$ and cigarette beetle control (Taiwan). ${ }^{34}$ Baek was a consultant for the $\$ 225000$ industry funded Korean indoor air quality 1993-4 analyses with UK industry consultant Roger Perry, ${ }^{58}$ and had been budgeted for $\$ 110000$ from PM in 1997-8. ${ }^{5960}$ Matsuki had received funding from Japan's Smoking Research Foundation (funded by Japan Tobacco), ${ }^{61}$ and worked with industry consultant 
Koo before. ${ }^{62}$ No relevant documents for industry consulting activities were found for Professors Kawamoto and Gao.

Regulatory issues within the USA and Japan were presented: debating the definition of "addiction", 32 "scientific implications of the U.S. 'settlement' proposal", ${ }^{32}$ risk assessment analysis (Tardiff, Sapphire Group; Starr, TBS Associates), ${ }^{36}$ the "scientific basis on the alleged medical cost of smoking" (Japan Tobacco), ${ }^{33}$ and "conflicts of advice" on smoking and health issues from outside of the industry (Japan Tobacco). ${ }^{34}$ In 1997, the transnational tobacco industry had been discussing a controversial settlement of all litigation for costs related to tobacco related disease, which eventually was not implemented, and possible regulation of cigarettes as nicotine delivery devices that caused addiction. ${ }^{63}$ Studies of various products were also described: $\mathrm{PM}^{\prime}$ s proposal to measure population smoke exposure with low tar products, ${ }^{38}$ and antioxidant studies for a "low free radical" Chinese cigarette (Xin, China's Institute of Biophysics). ${ }^{38}$ The transnational tobacco companies have been interested in developing products that reduce toxins as an alternative to reducing tobacco related disease and death. ${ }^{64}$ No relevant documents on Xin were found.

Accommodating smokers and non-smokers with ventilation were promoted: Japan Tobacco's "courtesy campaign", ${ }^{30}$ indoor air pollution in Japan (Kodama, Japan's University Occupational and Environmental Health), ${ }^{37}$ development of ventilation systems to reduce secondhand smoke (Japan Tobacco), ${ }^{37}$ and "Technological Options for Accommodation" (PM). ${ }^{37}$ PM had developed initiatives to "accommodate" smokers and non-smokers in the same room as an alternative for smoke-free areas, including ventilation technologies and communication programmes promoting "courtesy". ${ }^{45-47}$ Japan's promotion of these strategies may reflect the close working relationship ${ }^{29}$ between PM and JT. Kodama had been listed as a PM-JT consultant, ${ }^{65-67}$ and helped with PM's Korean indoor air quality study ${ }^{68}$

Besides the formal presentations, articles were distributed to ARTIST members, including work done by the transnational industry's consultants, ${ }^{18}{ }^{19} 23$ on personal monitoring studies and secondhand smoke epidemiology, and company reviews on secondhand smoke science. ${ }^{30} 32$ Starting in 1997, ARTIST members were encouraged to present a brief summary and comment on interesting regional scientific publications. ${ }^{34}{ }^{38}$ Emerging scientific and regulatory issues for each country were also routinely discussed. For example, in 2000 these issues included smoking lawsuits in Korea, tobacco tax increases in Taiwan, a report on "Smoking and human's health" in China, and government indoor air quality guidelines in Hong Kong. ${ }^{38}$

\section{Not just science}

As ARTIST evolved, PM wanted the organisation to continue serving as a communication vehicle, but not just for scientific interaction between the tobacco companies. Roger Walk described to Rick Solana (vice-president of Philip Morris' worldwide scientific affairs) that the 2001 10th ARTIST scientific symposium with industry and non-industry scientists on "Biomarkers of Tobacco Exposure" was "a great scientific program from which PM scientists and the other attending scientists will benefit scientifically". ${ }^{69}$ However, Solana wrote back:

\footnotetext{
"...I don't see this [symposium] as a great opportunity in which we will benefit. To me, a great opportunity is interaction with the scientific and public health communities where we might be able to move our reduced harm efforts forward. This [symposium] is a use of resources which does not have that great of a payback. If it were a
}

truly public forum, which this is not, it would be more valuable... I would like to see the ratio (between our interactions with the outside scientific and public health community and our interactions with industry scientists) in Asia be more towards the external interactions ${ }^{\prime \prime 70}$

Discussing scientific and regulatory issues among industry scientists alone was not seen as valuable to PM's executives. Solana wanted to promote PM's "reduced harm efforts" with the external scientific and public health community in Asia. "Reduced harm" refers to a rekindled debate about decreasing tobacco toxin exposure without eliminating nicotine and tobacco to reduce human disease and death, and the transnational tobacco industry has been discussing research directions with some scientists, policymakers, and tobacco control advocates. ${ }^{64}$

PM's worldwide scientific affairs "Communication 2001Asia" plan specifies PM's target audiences and goals. ${ }^{71} \mathrm{PM}^{\prime} \mathrm{s}$ goal for "Public Health Community and Regulators" was to "develop a dialogue on solutions to public health/regulatory issues", briefing public health/regulatory scientists on reduced harm products and inviting selected public health representatives to ARTIST meetings. For the external "Scientific Community", PM's goal was "being regarded as a credible source of knowledge and research support for smoking and health related issues", by funding regional external scientists and participating in scientific conferences. As for the "Industry Scientists", PM would continue "open exchange on non-proprietary information", such as its ongoing studies and submissions to scientific or regulatory bodies. In May 2001, PM's Walk told Solana that ARTIST planned to discuss a name change, ${ }^{69}$ and further documents beyond this date were not found.

\section{DISCUSSION}

The Asian tobacco industry landscape has changed from an environment of invasion to an environment of participation. ARTIST, an industry organisation of Asian scientific representatives, was initially created to coordinate PM's strategies in preventing global smoke-free areas with the IARC secondhand smoke study. After the IARC study's publication did not lead to immediate global smoke-free areas, ARTIST became a forum for presenting scientific and regulatory concerns of the transnational tobacco industry. The major Asian tobacco monopolies were gradually incorporated, strengthening ARTIST's outreach. The prominence of Japan Tobacco in ARTIST reflects a long working relationship since the 1980s between Philip Morris and Japan Tobacco on smoking and health issues and minimising health risks. ${ }^{13}$ Despite ARTIST's charter's stated purpose, ARTIST was not meant to improve scientific discussions alone. Beginning in 2001, PM executives wanted to use ARTIST as a communication vehicle for promoting its scientific credibility to public health community and regulators, and the external scientific community.

The impact of ARTIST on issues like secondhand smoke and reduced harm products is yet to be determined, and may become more prominent when the World Health Organization's Framework Convention on Tobacco Control, ${ }^{72}$ which provides guidelines for countries to implement tobacco control, is ratified. The Asian members of ARTIST are not government representatives, but as scientific representatives of their local tobacco monopoly or private company, they may be a conduit of influence in determining their country's priorities in tobacco control. It is difficult to determine the motivations of the Asian tobacco monopoly and private company scientific representatives in joining ARTIST, as the documents analysed are from the transnational tobacco industry. Also, the documents on ARTIST extend only 


\section{What this paper adds}

The transnational tobacco industry has a history of aggressively entering the Asian market, which has the world's largest percentages of smokers. Local Asian tobacco monopolies and companies are in direct competition as trade barriers are removed. Different tobacco control priorities exist in each Asian country.

The Asian tobacco industry has changed from an environment of invasion by transnational tobacco companies to an environment of participation with Philip Morris' initiated activities. Philip Morris began an industry organisation of scientific representatives, the Asian Regional Tobacco Industry Science Team (ARTIST), that includes the local Asian tobacco monopolies and companies. ARTIST has become a forum for Philip Morris' scientific and regulatory agenda. Philip Morris' goal for ARTIST is to reach out to the external scientific and public health community and regulators in Asia. This inter-industry participation will present challenges for effective tobacco control implementation in Asia.

through May 2001, when PM noted the name would be changed, and further activities may be ongoing.

Outside of Asia, the transnational tobacco industry has a long history of cooperation on smoking and health issues. The Confederation of European Community Cigarette Makers (CECCM) is a political organisation that coordinates the major European Community manufacturers, and worked against a recent European Community advertising ban. ${ }^{73}$ The Cooperation Centre for Scientific Research Relative to Tobacco (CORESTA), initially a tobacco industry chemist research organization founded in 1955 by European tobacco monopolies, includes both state monopolies and transnational companies and has shaped the international tobacco standards for nicotine and $\operatorname{tar}^{74}$ The International Tobacco Information Center (INFOTAB), previously named International Council on Smoking Issues when established in 1971, is an international network of tobacco companies, leaf dealers, and national manufacturers' associations whose formal agreement is to cooperate on non-competitive issues. ${ }^{75}$ Throughout the 1980s and 1990s, CORESTA and INFOTAB transformed into political instruments with lobbying government officials and United Nation organisations to prevent tobacco control from becoming a developing country issue, and countering WHO health advocacy programmes and regulation on issues such as pesticides. ${ }^{76}$ The transnational tobacco companies have also collaborated in the "International ETS Consultants" programme hiring external consultants from host countries, including Asia, ${ }^{20}{ }^{21}$ to influence public opinion on secondhand smoke with viewpoints favourable to the industry. ${ }^{18} 19$ In the mid 1980s, a newly privatised Japan Tobacco and PM began coordinating positions against tobacco control efforts, ${ }^{13}$ and their partnership is reflected in the joint leadership of ARTIST. Before ARTIST, though, widespread regional organisation of the various tobacco monopolies and private companies within Asia had not been seen with the transnational tobacco industry's activities.

More than exporting tobacco itself, PM and other transnational companies are exporting their scientific and regulatory agendas to the local Asian tobacco monopolies and private companies. The globalisation of production and marketing campaigns by the transnational tobacco industry into developing countries is expected to have a large impact on increasing the rates of non-communicable disease with increased cigarette sales. ${ }^{77}$ Debate continues about how much trade liberalisation will impact effective tobacco control by governments, ${ }^{78} 79$ although transnational companies are already sidestepping the export issue by relocating their manufacturing directly to developing countries ${ }^{80}{ }^{80}$ The WHO's Framework Convention on Tobacco Control encourages governments to adopt proven tobacco control strategies in advertising, taxes, and regulations, ${ }^{72}$ and various Asian governments have already signed the treaty and adopted stronger tobacco control measures. However, Asian governments may be increasingly challenged by sophisticated and coordinated strategies from the transnational tobacco companies. The Asian tobacco industry may be becoming more homogenous in adopting transnational scientific and regulatory positions through industry organisations such as ARTIST. More cooperation and adaptation of strategies between transnational tobacco companies and local tobacco monopolies or private companies should be expected. As a result, the global tobacco control community similarly needs to respond and establish stronger collaborations.

\section{Authors' affiliations}

E K Tong, Division of General Internal Medicine, University of California, San Francisco, San Francisco, California, USA

S A Glantz, Center for Tobacco Control Research and Education, University of California, San Francisco, San Francisco, California, USA This work was supported by NRSA 1-T32-HP 19025 and NCl grant CA87472.

No competing interests are declared by the authors. Ethics committee approval was not applicable to this analysis.

\section{REFERENCES}

1 Chen $\Pi$, Winder AE. The opium wars revisited as US forces tobacco exports in Asia. Am J Public Health 1990;80:659-62.

2 Muggli ME, Pollay RW, Lew R, et al. Targeting of Asian Americans and Pacific Islanders by the tobacco industry: results from the Minnesota Tobacco Document Depository. Tobacco Control 2002;11:201-9.

3 O'Sullivan B, Chapman S. Eyes on the prize: transnational tobacco companies in China 1976-1997. Tobacco Control 2000;9:292-302.

4 Lew R, Tanjasiri SP. Slowing the epidemic of tobacco use among Asian Americans and Pacific Islanders. Am J Public Health 2003;93:764-8.

5 Fagan P, King G, Lawrence D, et al. Eliminating tobacco-related health disparities: directions for future research. Am J Public Health 2004;94:21 1-7.

6 Jha P, Ranson MK, Nguyen SN, et al. Estimates of global and regional smoking prevalence in 1995, by age and sex. Am J Public Health 2002;92:1002-6.

7 Chaloupka FJ, Laixuthai A. U.S. trade policy and cigarette smoking, 1996. Report No.: Working Paper No. 5543.

8 Jha P, Chaloupka F. Curbing the epidemic: governments and the economics of tobacco control. Washington DC: The World Bank, 1999. Report No.:ISBN 08213-4519-2.

9 Zhong Wu. Money-spinning habit. Hong Kong Standard 2004 April 7.

10 Chantornvong S, McCargo D. Political economy of tobacco control in Thailand. Tobacco Control 2001;10:48-54.

11 Sato H. Policy and politics of smoking control in Japan. Soc Sci Med 1999;49:581-600.

12 Tobacco Free Japan. Tobacco free Japan: recommendations for tobacco control policy. Tokyo, Japan: INKS, Inc, and Institute for Global Tobacco Control, Johns Hopkins Bloomberg School of Public Health, 2003.

13 lida Ki, Proctor RN. Learning from Philip Morris: Japan Tobacco's strategies regarding evidence of tobacco health harms as revealed in internal documents from the American tobacco industry. Lancet 2004;363:1820-4.

14 Kang HY, Kim HJ, Park TK, et al. Economic burden of smoking in Korea. Tobacco Control 2003; 12:37-44.

15 Hsueh Hung-fu. TTL labor union protests government's plans for privatization. Taiwan News 2003 November 2

16 Tsai YW, Sung HY, Yang CL, et al. The behaviour of purchasing smuggled cigarettes in Taiwan. Tobacco Control 2003;12:28-33.

17 Ong EK, Glantz SA. Constructing "sound science" and "good epidemiology": tobacco, lawyers, and public relations firms. Am J Public Health 2001;91:1749-57.

18 Barnoya J, Glantz S. Tobacco industry success in preventing regulation of secondhand smoke in Latin America: the "Latin Project". Tobacco Control 2002;11:305-14.

19 Muggli ME, Hurt RD, Blanke DD. Science for hire: a tobacco industry strategy to influence public opinion on secondhand smoke. Nicotine Tob Res 2003;5:303-14.

20 Assunta M, Fields N, Knight J, et al. "Care and feeding": the Asian environmental tobacco smoke consultants programme. Tobacco Control 2004; 13(suppl II):ii4-12.

21 Barnoya J, Glantz S. The tobacco industry's worldwide ETS consultants project: European and Asian components. Eur J Public Health (in press). 
22 Boffetta P, Agudo A, Ahrens W, et al. Multicenter case-control study of exposure to environmental tobacco smoke and lung cancer in Europe. J Natl Cancer Inst 1998;90:1440-50.

23 Ong EK, Glantz SA. Tobacco industry efforts subverting International Agency for Research on Cancer's second-hand smoke study. Lancet 2000;355:1253-9.

24 Legacy Tobacco Documents Library. Guildford Archiving Project Questions \& Answers. University of California San Francisco, 2004. http:// bat.library.ucsf.edu/q_a.html [Accessed 2 Aug 2004]

25 Lee D. Facsimile Transmission [Memo from Lee to Walk]. 15 Mar, 1996. Philip Morris. Bates No. 2073894552/4553. http://legacy.library.ucsf.edu/tid/ izn85c00 [Accessed 1 Apr 2004].

26 Walk R. Fax Message 1 st Meeting of Asian Tobacco Industry ETS Science Team. 20 Mar, 1996. Philip Morris. Bates No. 2073894548/4549. http:// legacy.library.ucsf.edu/tid/fzn85c00 [Accessed 1 Apr 2004].

27 Area of Charles Green. 1 st Meeting of Asian Regional Tobacco Industry Scientists Team "ARTIST". 24 May, 1996. RJ Reynolds. Bates No. 517529614/9616. http:///egacy.library.ucsf.edu/tid/syh01d00 [Accessed 1 Apr 2004]

28 Sears SB. Artist Meeting January 17-18, 1999. 8 Feb, 1999. RJ Reynolds. Bates No. 521113623/3625. http://legacy.library.ucsf.edu/tid/opz20d00 [Accessed 1 Apr 2004].

29 Fowler GL. Meeting at Japan Tobacco Inc. 930415. 23 Apr, 1993. Philip Morris. Bates No. 2500054203/4205. http://legacy.library.ucsf.edu/tid/ eqy71c00 [Accessed 18 Apr 2004]

30 Office of Roger Walk. 2nd Meeting Asian Region Tobacco Industry Scientists Team. 7 Nov, 1996. Philip Morris. Bates No. 2073894628. http:// legacy.library.ucsf.edu/tid/eon85c00 [Accessed 1 Apr 2004]

31 Area of Charles Green. 3rd Meeting of Asian Regional Tobacco Industry Science Team "Artist". 26 May, 1997. RJ Reynolds. Bates No. 517529210/ 9214. http://legacy.library.ucsf.edu/tid/tkj82d00 [Accessed 2 Apr 2004]

32 Area of Richard Carchman. 4th Meeting of Asian Regional Tobacco Industry Science Team 'Artist' 970902, 9:00 H to 17:15 H Shagri La Hotel, Kuala Lumpur, Malaysia. 2 Sep, 1997. Philip Morris. Bates No. 2063626299/ 6304. http://legacy.library.ucsf.edu/tid/gvi67e00 [Accessed 1 Apr 2004]

33 Office of T Sanders. Agenda ARTIST Mini Symposium and 6th ARTIST Meeting 990118 JW Marriott Hotel, Bangkok, Thailand Mini Symposium. 12 Jan, 1999. Philip Morris. Bates No. 2505659593. http:// legacy.library.ucsf.edu/tid/jmu15c00 [Accessed 2 Apr 2004].

34 Office of M Zimmerman. Summary of the 9th ARTIST Meeting. 6 Nov, 2000 Philip Morris. Bates No. 2082647201/7204. http://legacy.library.ucsf.edu/ $\mathrm{tid} / \mathrm{tku} 55 \mathrm{c00}$ [Accessed 2 Apr 2004]

35 Area of A Lenling. Draft Agenda 000510 (Thursday) Mini Symposium on Biomarkers Related to Smoking [10th ARTIST meeting]. 3 Apr, 2001. Philip Morris. Bates No. 2081359359. http://legacy.library.ucsf.edu/tid/hlr81c00 [Accessed 2 Apr 2004]

36 Office of SB Sears. ARTIST Mini Symposium [5th meeting]. 27 Apr, 1998. RJ Reynolds. Bates No. 518987038/7042. http://legacy.library.ucsf.edu/tid/ nnp01d00 [Accessed 2 Apr 2004]

37 Office of K Osbourne. ARTIST Minutes Mini Symposium and 7th Meeting Mon. 991018 Room Hiei, Kyoto Takaragaike Prince Hotel. 18 Oct, 1999. Philip Morris. Bates No. 2082063233/3235. http://legacy.library.ucsf.edu/ $\mathrm{tid} /$ iyo46c00 [Accessed 2 Apr 2004].

38 Office of K Osbourne. Summary of ARTIST Mini Symposium and 8th Meeting Mon. 20000417 Luxury Hall, Minzu Hotel, Beiijing, China. 17 Apr, 2000 Philip Morris. Bates No. 2082063220/3222. http://legacy.library.ucsf.edu/ $\mathrm{tid} /$ byo46c00 [Accessed 2 Apr 2004].

39 Zhang M. Distribution of Documents of Interest. 11 Nov, 1997. RJ Reynolds. Bates No. 518987316/7322. http://legacy.library.ucsf.edu/tid/yss01d00 [Accessed 1 Apr 2004].

40 Lau RW. Taiwan Tobacco and Wine Board Joins ARTIST. 5 Oct, 1999. Philip Morris. Bates No. 2078588373. http://legacy.library.ucsf.edu/tid/ whc19c00 [Accessed 2 Apr 2004].

41 Walk R. Facsimile Cover Sheet [Reply to Hasan Sulaiman]. 2000:2082676897.

42 Walk R. Fax Message [to RJ Reynolds]. 20 Mar, 1996. Philip Morris. Bates No. 2073894546/4547. http://legacy.library.ucsf.edu/tid/ezn85c00 [Accessed 1 Apr 2004].

43 Lee PN. "Marriage to a smoker" may not be a valid marker of exposure in studies relating environmental tobacco smoke to risk of lung cancer in Japanese non-smoking women. Int Arch Occup Environ Health 1995;67:287-94.

44 Hong MK, Bero LA. How the tobacco industry responded to an influential study of the health effects of secondhand smoke. BMJ 2002;325:1413-6.

45 Drope J, Bialous SA, Glantz SA. Tobacco industry efforts to present ventilation as an alternative to smoke-free environments in North America. Tobacco Control 2004;13(suppl I):i41-7

46 Bialous SA, Glantz SA. ASHRAE Standard 62: tobacco industry's influence over national ventilation standards. Tobacco Control 2002;11:315-28.

47 Dearlove JV, Bialous SA, Glantz SA. Tobacco industry manipulation of the hospitality industry to maintain smoking in public places. Tobacco Control 2002; 11:94-104.

48 Area of Mark Berlind. Charter of ARTIST. 26 Jan, 1999. Philip Morris. Bates No. 2072522752/2754. http://legacy.library.ucsf.edu/tid/fya06c00 [Accessed 1 Apr 2004]

49 Friedman M. Artist Charter. 13 Sep, 1998. Philip Morris. Bates No. 2060570389. hittp://legacy.library.ucsf.edu/tid/efb13e00 [Accessed 1 Apr 2004].

50 Ellis C. Artist Charter. 14 Sep, 1998. Philip Morris. Bates No. 2060570388 http://legacy.library.ucsf.edu/tid/mfbl3e00 [Accessed 1 Apr 2004].
51 Friedman MP. Fax Cover Sheet Artist. 11 Feb, 1999. Philip Morris. Bates No. 2072522751. http://legacy.library.ucsf.edu/tid/eya06c00 [Accessed 1 Apr 2004].

52 Area of Roger Walk. What This Means. 26 May, 1997. Philip Morris. Bates No. 2073894852. http://legacy.library.ucsf.edu/tid/jpn85c00 [Accessed 2 Apr 2004].

53 Walk R. Facsimile Cover Sheet Budget Joint JT-PM Asian Consultant Activities Program. 21 Jan, 1997. Philip Morris. Bates No. 2078593003/3004. http://legacy.library.ucsf.edu/tid/htr25c00 [Accessed 2 Apr 2004]

54 Office of Roger Walk. Response Plan Asia. 29 Oct, 1996. Philip Morris. Bates No. 2073894562. http://legacy.library.ucsf.edu/tid/nzn85c00 [Accessed 2 Apr 2004].

55 Area of Roger Walk. 2nd Meeting Asian Region Tobacco Industry Scientists Team [handwritten notes]. 5 Nov, 1996. Philip Morris. Bates No. 2073894590. http://legacy.library.ucsf.edu/tid/tzn85c00 [Accessed 2 Apr 2004].

56 Walk R, Zhang M. Scientific Resource Book. 4 Apr, 1997. Philip Morris. Bates No. 2505514025/4162. http://legacy.library.ucsf.edu/tid/ogm94c00 [Accessed 3 Apr 2004].

57 Barnes DE, Bero LA. Why review articles on the health effects of passive smoking reach different conclusions. JAMA 1998;279:1566-70.

58 Office of A Spears. Proposal for an Indoor Air Quality Monitoring Study in Kore A. 21 Oct, 1993. Lorillard. Bates No. 89273097/3111. http:// legacy.library.ucsf.edu/tid/pei01e00 [Accessed 19 Apr 2004].

59 Office of Roger Walk. Research \& Development $980000 \mathrm{Ob}$ Consulting Services Functional Area: Scientific Affairs Asia Japan Australia ( $\$$ in 000 's). 27 Jan, 1998. Philip Morris. Bates No. 2073796066. http:// legacy.library.ucsf.edu/tid/zwu85c00 [Accessed 19 Apr 2004].

60 To D. Scientific Affairs Asia Japan Australia Original Budget 970000 Vs Actual Expenses 970000. 2 Sep, 1998. Philip Morris. Bates No. 2073796044. http://legacy.library.ucsf.edu/tid/jwu85c00 [Accessed 19 Apr 2004].

61 Homma H. [Research projects of Japan Smoking Research Foundation]. Jun, 1998. Philip Morris. Bates No. 2060568044/8051. http:// legacy.library.ucsf.edu/tid/xtc13e00 [Accessed 19 Apr 2004]

62 Rupp JP. [Matsuki working with Koo]. 5 May, 1994. Philip Morris. Bates No. 2023000668. http://legacy.library.ucsf.edu/tid/tbo87e00 [Accessed 19 Apr 2004]

63 Givel M, Glantz SA. The "global settlement" with the tobacco industry: 6 years later. Am J Public Health 2004;94:218-24.

64 Hatsukami DK, Slade J, Benowitz NL, et al. Reducing tobacco harm: research challenges and issues. Nicotine Tob Res 2002;4(suppl 2):S89-101.

65 Rupp J. [Memo of Asia industry consultants including Kodama]. 4 Nov, 1993. Philip Morris. Bates No. 2025837637/7639. http://legacy.library.ucsf.edu/ $\mathrm{tid} / \mathrm{ipd} 87 \mathrm{e} 00$ [Accessed 19 Apr 2004]

66 Area of Richard Carchman. Budget for JT-PM ETS Consultant Program, Asia [Kodama]. 9 Aug, 1996. Philip Morris. Bates No. 2063604699. http:// legacy.library.ucsf.edu/tid/adn67e00 [Accessed 19 Apr 2004]

67 Walk R. Facsimile Balance JT-PM Consultant Program. 3 Apr, 1998. Philip Morris. Bates No. 2063651094/1096. http://legacy.library.ucsf.edu/tid/ erg67e00 [Accessed 19 Apr 2004]

68 Perry R. [Memo about Korean study delay to lawyer Rupp and mentioning Kodama]. 19 Aug, 1994. Philip Morris. Bates No. 2048771087/1089. http://legacy.library.ucsf.edu/tid/Inn32d00 [Accessed 19 Apr 2004]

69 Walk R. Fw: Draft Agenda ARTIST Meeting Singapore, 000510000511. 5 Apr, 2001. Philip Morris. Bates No. 2081502539A. http:// legacy.library.ucsf.edu/tid/kbw82c00 [Accessed 3 Apr 2004]

70 Solana RP. Re: Draft Agenda ARTIST Meeting Singapore, 000510000511 5 Apr, 2001. Philip Morris. Bates No. 2081502539. http:// legacy.library.ucsf.edu/tid/lbw82c00[Accessed 3 Apr 2004].

71 Area of Roger Walk. Communication 20010000 Asia. 11 Dec, 2000. Philip Morris. Bates No. 2082675404/5407. http://legacy.library.ucsf.edu/tid/ fbt55c00[Accessed 3 Apr 2004].

72 World Health Organization Tobacco Free Initiative. WHO Framework Convention on Tobacco Control [Accessed April 2004]

73 Neuman M, Bitton A, Glantz S. Tobacco industry strategies for influencing European Community tobacco advertising legislation. Lancet 2002;359:1323-30.

74 Bialous SA, Yach D. Whose standard is it, anyway? How the tobacco industry determines the International Organization for Standardization (ISO) standards for tobacco and tobacco products. Tobacco Control 2001;10:96-104.

75 Carter SM. Cooperation and control: the Tobacco Institute of Australia. Tobacco Control 2003;12(suppl III):iii54-60.

76 Committee of Experts on Tobacco Industry Documents. Tobacco company strategies to undermine tobacco control activities at the World Health Organization. Geneva, Switzerland: World Health Organization, 2000 July. Report No. Paper WHO7.

77 Beaglehole RDY. Globalisation and the prevention and control of noncommunicable disease: the neglected chronic diseases of adults. Lancet 2003;362:903-8

78 Bettcher D, Shapiro I. Tobacco control in an era of trade liberalisation. Tobacco Control 2001;10:65-7.

79 Callard C, Chitanondh H, Weissman R. Why trade and investment liberalisation may threaten effective tobacco control efforts. Tobacco Control 2001; 10:68-70.

80 Hammond R. Consolidation in the tobacco industry. Tobacco Control 1998;7:426-8. 